\title{
Suicidally motivated intoxication by psychoactive drugs: characterization among the elderly
}

Igho Leonardo do Nascimento Carvalho' Ana Paula Antero Lôbo' Clayre Anne de Araújo Aguiar² Adriana Rolim Campos'

\section{Abstract}

Objective: to characterize suicidally motivated intoxication by psychoactive drugs among elderly people. Method: a retrospective and documentary study with a quantitative approach was carried out, based on the notification forms of 692 cases of suicidally motivated intoxications by psychoactive drugs, registered by the Centro de Assistência Toxicológica (the Toxicological Care Center) in Fortaleza, Ceará, Brazil from 2010 to 2014. The absolute and relative frequencies of social conditions, intoxication episodes and clinical conducts were obtained, and the Chi-squared Test was applied with a significance of $p \leq 0.05$. Results: elderly people aged between 60 and 69 years $(65.9 \%)$, who were female and retired predominated. The most frequently used psychoactive drugs were antidepressants $(48.3 \%)$ and anxiolytics/hypnotics (29.0\%). The most frequent clinical conducts were the use of activated charcoal and gastric lavage. Moderate poisoning was the most frequent, and the main outcome was discharge arising from cure. There was a significant relationship between the elderly persons and gender, occupation, occurrence of intoxication at home, clinical manifestation and hospital admission. Conclusion: suicidally motivated poisoning by psychoactive drugs in elderly persons suggests the need to promote active aging, as well as the access to and rational use of these drugs, thereby reducing harm and preserving the lives of elderly persons.

\footnotetext{
Universidade de Fortaleza (UNIFOR), Vice-reitoria de Pós-Graduação, Programa de Pós-Graduação em Saúde Coletiva. Fortaleza, Ceará, Brasil.

2 Instituto Dr. José Frota (IJF), Internação Cirúrgica. Fortaleza, Ceará, Brasil.
}

Correspondence

E-mail: igho_leonardo@yahoo.com.br

\section{Keywords: Suicide} Attempted. Psychotropic Drugs. Comprehensive Health Care for the Elderly. 


\section{INTRODUCTION}

Senility brings many diseases that require treatment based on the use of psychoactive drugs, medications that affect mental and emotional functioning ${ }^{1}$. The use of psychoactive drugs can lead to intoxication, which is understood as a set of signs and symptoms that cause an organic imbalance, resulting in damage or death ${ }^{2}$.

There are few studies that address the characteristics of suicidally motivated intoxication by psychoactive drugs among the elderly, despite the understanding that an association exists between such factors ${ }^{3,4}$. Yet suicidal motivation is considered a predictor of suicide, which is a global public health problem ${ }^{5}$.

According to the World Health Organization (WHO), suicide is responsible for the deaths of around one million people around the world every year. China has the highest suicide rate among elderly persons (100 deaths per 100,000 inhabitants), while in South Korea the risk of suicide and suicide attempts among the elderly was 70.7 and 13.1/100,000 inhabitants, respectively. In the USA, the risk is $10.8 / 100,000$ inhabitants ${ }^{6,7}$.

In Brazil, the rates of suicide are low compared with the majority of countries, oscillating between 3.50 and 5.80/100,000 inhabitants. However, the rates for the elderly, considered to be individuals aged 60 years or over, are twice those of the general population ${ }^{1,2,8,9}$.

A study about the suicide of the elderly, using the psychological autopsy technique in which post mortem information about the circumstances and situations of the suicide is gathered together, reported that between 71 and $95 \%$ of elderly people who committed suicide were diagnosed with a mental disorder at the time of death, while from 71 to $90 \%$ suffered from some degree of depression ${ }^{3,8}$.

In this context, the holistic conception is often neglected in favor of the indiscriminate use of psychoactive drugs, based on the medicalization of the elderly, which is strongly influenced by the biomedical model ${ }^{10-12}$. Supporting this theory, it was observed that there are no programs, actions or strategies directed at the safe use of psychoactive drugs by the elderly in the Unified Health System.

The characteristics of suicidally motivated intoxication by psychoactive drugs among the elderly represent a health problem. At the same time, they stimulate reflections on the use of psychoactive drugs by the elderly and on health actions directed at the prevention of these episodes and their recurrence ${ }^{13,14}$.

The present study on suicidally motivated intoxication by psychoactive drugs can contribute to a number of health services, establishing individual and collective strategies to promote the safe and rational use of medications ${ }^{13}$, and forming part of the agenda of actions directed at the integral care of the health of the elderly person. Therefore, the present study aimed to characterize suicidally motivated intoxications by psychoactive drugs among the elderly.

\section{METHOD}

A retrospective documentary study with a quantitative approach was carried out, based on the Notification Forms of registered intoxications by psychoactive drugs from 2010 to 2014, recorded at the Centro de Assistência Toxicológica (the Toxicological Care Center) (CEATOX) of the Instituto Dr. José Frota (IJF) in Fortaleza, Ceará, a referral center for the care of victims of intoxication.

There were 1,362 reports of drug intoxication in the five-year period studied, of which 692 were caused by psychoactive drugs and were motivated by suicide. Of this total, 25 intoxications involved the elderly, equivalent to $3.6 \%$ of the cases in the studied period.

All the treatment records of elderly persons who fit the following inclusion criteria were analyzed: aged at least 60 years at the time of being treated at CEATOX, registration of medication as cause of intoxication, and diagnostic classification in accordance with the International Code of Diseases (CID-10). 
Data collection took place in June and August 2015, with a semi-structured form based on the Notification Form, containing information relating to patient data, intoxication characteristics and clinical conduct adopted.

The social characteristics of the patients included the following variables: gender; current age in complete years; and occupation. The intoxication characteristics included the variables: location where intoxication occurred, which can be in the patient's residence or in an external environment; type of intoxication, being classified as single acute or repeated acute; route of administration; form of medication, which could be solid or not informed; quantity of agents used in intoxication; combined use of other substances; time elapsed from exposure to psychoactive drug until arrival at hospital.

The characteristics of clinical conduct included: presence of clinical manifestation; need for hospitalization; length of hospital stay shorter or longer than 24 hours; conduct adopted for treatment of intoxication by psychoactive drugs, which could be gastric lavage/activated charcoal/ hydration/clinical observation; assessment of mild/moderate/severe poisoning; classification of outcome, which was either hospital discharge, discharge on request, discharge against medical advice, transferred, or not found.

The analysis of the data involved obtaining the frequency measures of the central tendencies of the variables related to socioeconomic profile, episodes of intoxication and clinical conduct, allowing descriptive statistics to be performed.

The absolute and relative frequencies of variables relating to social profile, episodes of intoxication and the clinical conduct of elderly persons who suffered suicidally motivated intoxication by psychoactive drugs were obtained and compared with those of other patients.

The relationship between social characteristics, episodes of intoxication and clinical conduct and suicidally motivated psychoactive drug intoxication among elderly persons, which was a dependent variable, was also analyzed, using the Chi-squared test $(\mathrm{p}<0.05)$.
The study was approved by the Research Ethics Committee of the Instituto Dr. José Frota, under protocol number $\mathrm{n}^{\circ}$ 1.060.172 (CAAE: 43543215.4.0000.5047).

\section{RESULTS}

The majority of elderly persons were aged between 60 and 69 years $(20 ; 80.0 \%)$, female $(19 ; 76.0 \%)$ and retired $(12 ; 48.0 \%)$. The majority of non-retired patients performed some kind of work activity (274; $41.0 \%$ ). Characteristics of intoxication showed that the most common location was in the patient's residence, through a single acute intoxication, via the oral route and with a pharmaceutical in solid form. It was also observed that there was a significant association between age, occupation and place of residence and elderly persons who suffered suicidally motivated intoxication by psychoactive drugs (Table 1).

A proportion of the elderly persons took a quantity of one, two or three drugs, while the taking of a single agent was most frequent among the other patients. The combined use of other substances was frequent among all patients who suffered suicidally motivated intoxication by psychoactive drugs (Table 1).

In terms of the distribution by pharmacological classes of the psychoactive drugs used in suicidally motivated intoxication by the elderly persons, there was a predominance of antidepressants (12; 48.3\%) and anxiolytic/hypnotic drugs (7; 29.0\%) (Figure 1).

The characteristics of the episodes of suicidally motivated intoxication by psychoactive drugs among elderly persons showed a period of treatment of over eight hours $(9 ; 36.0 \%)$, while other patients were treated for between one and eight hours (383, $57.3 \%$ ). The majority of the elderly persons exhibited manifestations and the need for hospitalization for a period of up to 24 hours, representing a significant relationship (Table 2).

Moderate poisoning was the most frequent, and the use of activated charcoal and gastric lavage were the predominant treatment conducts adopted. Hospital discharge was the most frequent outcome, and was statistically significant. Most of the characteristics of the intoxication episodes and the clinical conducts of other patients were similar to those of the elderly patients (Table 2). 
Table 01. Social characteristics of elderly persons and of episodes of suicidally motivated intoxication by psychoactive drugs. Fortaleza. Ceará. 2010-2014.

\begin{tabular}{|c|c|c|c|}
\hline Variable $(n=692)$ & $\begin{array}{l}\text { Elderly persons }(\mathrm{n}=25) \\
\mathrm{n}(\%)\end{array}$ & $\begin{array}{l}\text { Other Patients }(\mathrm{n}=667) \\
\mathrm{n}(\%)\end{array}$ & $p^{*}$ \\
\hline $\begin{array}{l}\text { Age (years) } \\
60-69 \\
70-79 \\
80-89\end{array}$ & $\begin{array}{l}20(80.0) \\
03(12.0) \\
02(8.0)\end{array}$ & & 0.00 \\
\hline $\begin{array}{l}\text { Gender } \\
\text { Male } \\
\text { Female }\end{array}$ & $\begin{array}{l}06(24.0) \\
19(76.0)\end{array}$ & $\begin{array}{l}213(32.0) \\
454(68.0)\end{array}$ & 0.97 \\
\hline $\begin{array}{l}\text { Occupation } \\
\text { Retired } \\
\text { Performed work activity } \\
\text { Unemployed } \\
\text { Student } \\
\text { Information not provided }\end{array}$ & $\begin{array}{l}12(48.0) \\
10(40.0) \\
01(1.5) \\
\quad- \\
03(12.0)\end{array}$ & $\begin{array}{l}15(2.5) \\
274(41.0) \\
66(9.8) \\
139(20.8) \\
173(25.9)\end{array}$ & 0.00 \\
\hline $\begin{array}{l}\text { Location of Intoxication } \\
\text { Residence } \\
\text { External Location }\end{array}$ & $\begin{array}{l}23(92.0) \\
02(8.0)\end{array}$ & $\begin{array}{c}650(97.4) \\
17(2.6)\end{array}$ & 0.03 \\
\hline $\begin{array}{l}\text { Type of Intoxication } \\
\text { Acute single } \\
\text { Acute repeated }\end{array}$ & $\begin{array}{l}25(100.0) \\
-\end{array}$ & $\begin{array}{l}637(95.5) \\
30(4.5)\end{array}$ & 0.55 \\
\hline $\begin{array}{l}\text { Administration Route } \\
\text { Oral }\end{array}$ & $25(100.0)$ & $667(100.0)$ & - \\
\hline $\begin{array}{l}\text { Form } \\
\text { Solid } \\
\text { Information not provided }\end{array}$ & $\begin{array}{l}17(68.0) \\
08(32.0)\end{array}$ & $\begin{array}{l}470(70.4) \\
182(29.6)\end{array}$ & 0.85 \\
\hline $\begin{array}{l}\text { Quantity of toxic agents } \\
01 \\
02 \\
03 \\
\text { Over } 3\end{array}$ & $\begin{array}{l}09(36.0) \\
08(32.0) \\
08(32.0) \\
\quad-\end{array}$ & $\begin{array}{c}350(52.4) \\
172(25.7) \\
88(13.1) \\
57(8.8)\end{array}$ & 0.58 \\
\hline $\begin{array}{l}\text { Combined with other substances } \\
\text { Yes } \\
\text { No }\end{array}$ & $\begin{array}{l}16(64.0) \\
09(36.0)\end{array}$ & $\begin{array}{l}320(47.9) \\
347(52.1)\end{array}$ & 0.11 \\
\hline
\end{tabular}

*p refers to Chi-squared test with a level of significance of $\leq 0.05$

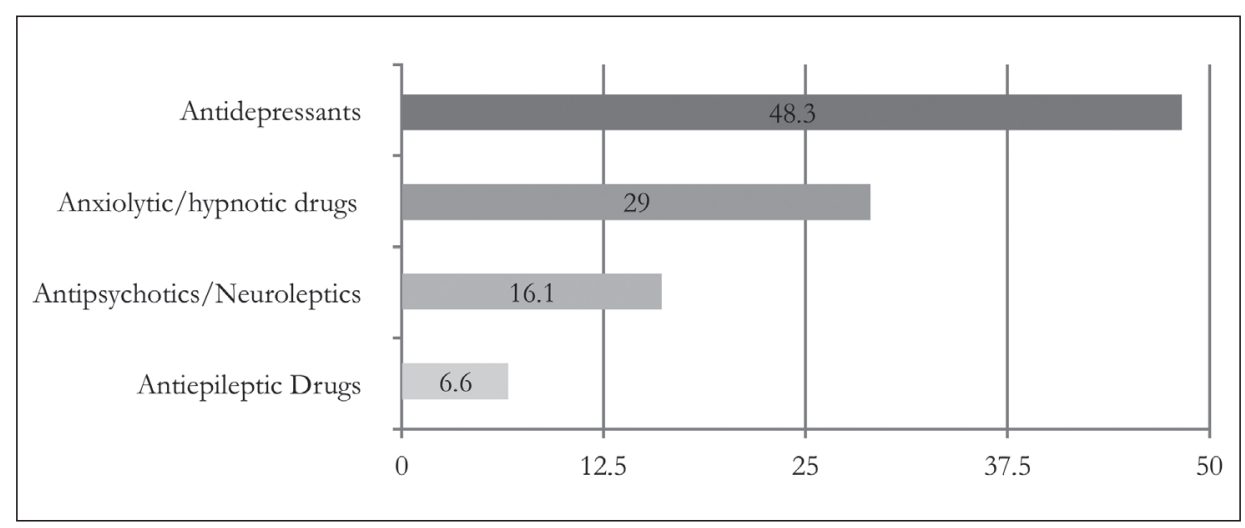

Figure 1. Distribution by pharmacological class of medications used in the suicidally motivated intoxication of elderly persons by psychoactive drugs. Fortaleza, Ceará, 2010-2014. 
Table 02. Characteristics of episodes of suicidally motivated intoxications by psychoactive drugs of elderly persons and clinical conduct. Fortaleza, Ceará, 2010-2014.

\begin{tabular}{|c|c|c|c|}
\hline Variable $(n=692)$ & $\begin{array}{l}\text { Elderly persons }(\mathrm{n}=25) \\
\mathrm{n}(\%)\end{array}$ & $\begin{array}{l}\text { Other Patients }(\mathrm{n}=667) \\
\mathrm{n}(\%)\end{array}$ & $p^{*}$ \\
\hline $\begin{array}{l}\text { Duration of Treatment (hours) } \\
01-04 \\
04-08 \\
\text { More than } 08 \\
\text { Information not provided }\end{array}$ & $\begin{array}{l}08(32.0) \\
05(20.0) \\
09(36.0) \\
03(12.0)\end{array}$ & $\begin{array}{l}264(39.5) \\
119(17.8) \\
180(26.9) \\
104(15.8)\end{array}$ & 0.65 \\
\hline $\begin{array}{l}\text { Clinical Manifestations } \\
\text { Yes } \\
\text { No }\end{array}$ & $\begin{array}{l}21(84.0) \\
04(16.0)\end{array}$ & $\begin{array}{c}654(98.0) \\
13(2.0)\end{array}$ & 0.00 \\
\hline $\begin{array}{l}\text { Hospitalization Required } \\
\text { Yes } \\
\text { No }\end{array}$ & $\begin{array}{l}21(84.0) \\
04(16.0)\end{array}$ & $\begin{array}{l}431(64.6) \\
236(35.4)\end{array}$ & 0.03 \\
\hline $\begin{array}{l}\text { Duration of Hospitalization (hours) } \\
\text { Up to } 24 \\
\text { Over } 24\end{array}$ & $\begin{array}{l}19(76.0) \\
06(24.0)\end{array}$ & $\begin{array}{l}459(68.8) \\
208(31.2)\end{array}$ & 0.46 \\
\hline $\begin{array}{l}\text { Clinical behavior** } \\
\text { Gastric lavage } \\
\text { Activated charcoal } \\
\text { Hydration } \\
\text { Clinical observation }\end{array}$ & $\begin{array}{l}11(44.0) \\
17(68.0) \\
05(20.0) \\
02(8.0)\end{array}$ & $\begin{array}{c}336(50.3) \\
445(66.7) \\
242(36.2) \\
35(5.2)\end{array}$ & - \\
\hline $\begin{array}{l}\text { Type of poisoning } \\
\text { Mild } \\
\text { Moderate } \\
\text { Severe } \\
\text { Not excluded }\end{array}$ & $\begin{array}{l}06(24.0) \\
11(44.0) \\
06(24.0) \\
02(8.0)\end{array}$ & $\begin{array}{c}197(29.5) \\
330(49.4) \\
123(18.4) \\
17(2.7)\end{array}$ & 0.33 \\
\hline $\begin{array}{l}\text { Outcome } \\
\text { Hospital discharge } \\
\text { Discharge on request } \\
\text { Discharge against medical advice } \\
\text { Transferred } \\
\text { Death } \\
\text { Not found }\end{array}$ & $\begin{array}{l}09(36.0) \\
03(12.0) \\
01(4.0) \\
03(12.0) \\
01(14.3) \\
08(4.0)\end{array}$ & $\begin{array}{c}395(59.2) \\
42(6.3) \\
18(2.7) \\
25(3.7) \\
06(1.0) \\
181(27.1)\end{array}$ & 0.07 \\
\hline
\end{tabular}

${ }^{*} \mathrm{p}$ refers to the Chi-squared test with a level of significance of $\leq 0.05 ; * *$ In the conduct variable the participants may have received more than one treatment resource

\section{DISCUSSION}

There was a low incidence of suicidally motivated intoxication by psychoactive drugs among the elderly, although the possibility of underreporting should be considered

The higher frequency of intoxication by psychoactive drugs among younger elderly persons (60 to 69 years old) ratifies data regarding the higher rate of suicide attempts among this age group. The group aged 70 or above, meanwhile, exhibited a high suicide rate and a low rate of intoxication as a suicide attempt $\mathrm{t}^{34}$.

A study carried out in China identified an incidence of elderly persons who had experienced self-mutilation, suicidal ideation and attempted suicide of $23.3 \%$. The frequency found by this study for younger elderly persons was $81 \%$, while for elderly persons aged 70 or older it was 
$68 \%{ }^{15}$. The study also demonstrated a significant association between age and the intoxicated elderly persons, which suggests that greater attention should be paid to the conditions that characterize the vulnerability of the elderly person.

Women suffered most frequently from suicidally motivated psychoactive drug intoxications. While this higher frequency may be associated with a greater consumption of psychoactive drugs and more frequent suicidal ideation among women, men arrive at the final act of suicide more often, most probably by using other methods ${ }^{1,9,16}$.

It is known that while men and women face the same degree of risk when suffering from a mental disorder linked to the ideation of suicide, the triggering factors are different, with the impossibility of performing work activities most affecting men, and family and conjugal conflicts most affecting women ${ }^{1,3}$.

The most frequent occupations reported by the elderly are retirement or the performance of work activities, while in the other patients the most frequent occupations were work and study activities. This finding reveals the influence of retirement on changing family and social roles ${ }^{17}$. The performance of work activities, in accordance with the individual's physical capabilities, makes elderly persons less vulnerable to suicide attempts, as it stimulates healthy aging by promoting social integration, autonomy and a sense of usefulness ${ }^{13,18}$.

The most frequent location of suicidally motivated intoxication by psychoactive drugs was in the home, a statistic which was significantly associated with elderly persons who suffered suicidally motivated intoxication by psychoactive drugs. The choice of the location to attempt suicide is probably based on the fact that the elderly person lives alone, despite suicide attempts through drug poisoning/intoxication presenting low lethality ${ }^{19}$.

The intoxications of the elderly persons were all classified as acute, single occurrences, characterized by short-term exposure and the rapid absorption of the toxic agent ${ }^{20}$. The first episode of intoxication should be dealt with urgently, but represents a challenge for a psychology outpatient clinic, as overcoming suicidally motivated intoxication without subsequent follow-up by a health professional can result in suicide in later years through accentuated social isolation and associated pathologies ${ }^{3,4}$.

Oral intoxication and the predominantly solid form of the psychoactive drugs are related to access, which in turn is based on medical prescription and the availability of the drugs in public pharmacies. In this sense, it is necessary to recognize the failings of public actions to prevent intoxication by psychoactive drugs among the elderly ${ }^{21}$.

There was an equitable distribution of the quantities of medications among the elderly, whereas among the other patients, the use of a single agent was more prevalent. In most cases, the drug was used in combination with other substances. These findings differ from a study on the use of psychoactive drugs among the elderly, which found the most frequent quantities to be one or two agents, with prevalences of $26 \%$ and $16.4 \%$, respectively ${ }^{14}$.

The vulnerability of the elderly to problems arising from the use of drugs is high, due to the complexity of clinical problems, the need for multiple therapeutic agents, and the pharmacokinetic and pharmacodynamic changes inherent in aging. Polypharmacy among the elderly reduces adherence to drug therapy and increases the frequency and severity of adverse reactions and drug interactions, adding to the risk of using potentially inappropriate drugs and, consequently, morbidity and mortality ${ }^{22,23}$.

The drugs most often used in the present study were the antidepressant and anxiolytic/hypnotic pharmaceutical classes. This finding is explained by the strong association between the diagnosis of depression and the use of psychoactive drugs $^{24,25}$. The use of antidepressants can result in vulnerability associated with the impairment of metabolism among elderly users ${ }^{26}$.

The treatment of depression requires the prolonged use of psychoactive drugs, but the 
absence of psychotherapy and the fact that the elderly persons live alone make such use unsafe, increasing the risk of socially motivated intoxication $^{13,14,27-29}$.

The most frequent treatment period for intoxication among the elderly persons was over eight hours, while the other patients were treated for between one and four hours. It is known that elderly persons who attempt to take their own lives are more likely to neither be found nor helped in a timely manner, as many of those who make up this age group live alone ${ }^{19}$.

Among the elderly persons, there was a predominance of clinical manifestations, with somnolence and sensory alteration the most frequent. This finding was statistically significant. The ingestion of a toxic quantity of antidepressants and anxiolytics/hypnotics potentiates a sedative effect, with the use of other toxic substances being a potential determinant ${ }^{29}$.

The need for hospitalization of the elderly for a period of up to 24 hours represented a statistically significant relationship. The short period of hospitalization may be related to the fact that specialized care at a referral center in toxicology was provided, resulting in a positive prognosis.

The most frequently used clinical conducts were the use of activated charcoal, gastric lavage, hydration and observation, respectively. These conducts constitute general treatment which, in turn, is much more effective than the search for a specific antidote ${ }^{20}$.

Activated charcoal is used in the majority of intoxications due to its absorbing action and, consequently, its reduction of toxic effects. Gastric lavage permits gastric emptying, immediate recovery of the gastric contents and access for the installation of activated carbon. Hydration decreases the concentration of the toxic agent. Both gastric lavage and hydration can eliminate the toxic agent from the body. Clinical observation is indicated for recording the evolution of the patient, the stability of vital signs and overcoming clinical manifestations ${ }^{20}$.
Intoxication by psychoactive drugs in the elderly in this study produced moderate poisoning and the most frequent outcome was discharge from hospital. Most people are discharged following a cure, when they are attended quickly and effectively by the emergency unit of any hospital where the health professional actions the CEATOX ${ }^{20}$.

The hospital discharge of elderly persons who suffered suicidally motivated intoxication by a psychoactive drug should not represent the termination of health care, but should involve the continued care of the elderly to observe their overall health condition. There is evidence that depression reappears among elderly persons within a period of two to three years in $50 \%$ to $90 \%$ of cases, making preventing the recurrence of suicidally motivated intoxication an objective following hospital discharge ${ }^{13}$.

The elderly should be included in risk detection and psychotherapeutic treatment programs to reduce the mortality rate by suicide by $60 \% \%^{13,27}$. In this context, psychotherapy is understood as a planned and structured intervention that influences behavior, mood and emotional patterns, assuming a transforming role in the lives of the elderly, as it redefines aging and prevents suicidally motivated intoxication ${ }^{11,14,29}$.

The recognition of protective factors is fundamental for the prevention of suicide attempts among the elderly. These include the support of family and friends and involving oneself in affective links, social protection and social and leisure meetings based on social integration and autonomy ${ }^{8,30}$. Family and social relationships, including the cultivation of friendships, are important protective factors against depression and suicidal ideation and should be considered a priority ${ }^{13,31}$.

It is important to recognize and understand the experiences and desires of elderly persons when considering the different ways of integrating such individuals socially. Engagement in social activities and in collective and creative projects should be considered as a suicide prevention strategy, as it promotes their well-being and quality of life, even when dependent ${ }^{18,32}$. 
Elderly persons must be respected as citizens and should be recognized as active, singular individuals, capable of producing subjective meanings and valuing their critical/reflexive capacity for life in a process of personal reconstruction and resignification, promoting active and healthy aging ${ }^{11,17,18}$.

The present study has some limitations, such as the assumption that suicidally motivated intoxication by psychoactive drugs is associated with depression. This information cannot be confirmed from the notification form, although such association is demonstrated by evidencebased health. The findings of the study refer to the suicidally motivated intoxication by psychoactive drugs, but due to the lack of research on this subject, these results were compared with actual suicide data.

\section{CONCLUSION}

Suicidally motivated intoxication by psychoactive drugs among the elderly was characterized by the age group 60 to 69 years, the female gender, and being retired. The most commonly used psychoactive drugs were

\section{REFERENCES}

1. Bruton LL. As bases farmacológicas da terapêutica de Goodman \& Gilman. $12^{\mathrm{a}}$ ed. Rio de Janeiro: McGraw Hill; 2012.

2. Oslon KR. Manual de toxicologia clínica. $6^{\mathrm{a}}$ ed. Editora McGraw Hill; 2013.

3. Minayo MCS, Cavalcante FG. Suicídio entre pessoas idosas: revisão de literatura. Rev Saúde Pública. 2010;44(4):750- 7.

4. Lovisi GM, Santos AS, Legay L, Abelha L, Valencia E. Análise epidemiológica do suicídio no Brasil entre 1980 e 2006. Rev Bras Psiquiatr. 2009;31(Supl 3):586-93.

5. Martins Junior DF, Felzemburgh RM, Dias AB, Caribé AC, Bezerra-Filho S, Miranda-Scippa A. Suicide attempts in Brazil, 1998-2014: an ecological study. BMC Public Health. 2016;16:2-8.

6. Zhong BL, Chiu HF, Conwell Y. Rates and characteristics of elderly suicide in China. J Affect Disord. 2016;206:273-9. antidepressants and anxiolytics/hypnotics, with the most frequent poisoning type being moderate and the main outcome being cured.

The characterization of suicidally motivated intoxication by psychoactive drugs among elderly persons suggests the need to promote active aging, developed by a multi-professional health team working in basic care. Access to and the rational use of psychoactive drugs, especially in the treatment of mental disorders, as well as psychotherapy, should be investigated as strategies to reduce intoxication by psychoactive drugs among the elderly.

It is fundamental to continue research into the multiple dimensions involved in these intoxications. Such research can support strategies that stimulate access to and the rational use of psychoactive drugs, preventing intoxication and preserving the lives of the elderly.

\section{ACKNOWLEDGEMENTS}

The authors would like to thank the Instituto Dr. José Frota (IJF) and the Universidade de Fortaleza (the University of Fortaleza) (UNIFOR).
7. Brasil. Ministério da Saúde, Secretaria de Atenção à Saúde, Departamento de Atenção Básica.

Envelhecimento e saúde da pessoa idosa [Internet]. Brasília, DF: Ministério da Saúde; 2007 [acesso em 22 set. 2016]. (Série A. Normas e Manuais Técnicos) (Cadernos de Atenção Básica; n. 19). Disponível em: http://bvsms.saude.gov.br/bvs/publicacoes/ envelhecimento_saude_pessoa_idosa_n19.pdf

8. Organização Mundial de Saúde. Adherence to long-term therapies: policy for action [Internet]. Geneva: WHO; 2001 [acesso em 20 out. 2016]. Disponível em: http:// www.who.int/chronic_conditions/en/adherencerep.pdf

9. Instituto Brasileiro de Geografia e Estatística. Séries históricas e estatísticas. Óbitos por causas externas - suicídio - taxa de mortalidade específica: 1990 - 2009; 2010. [acesso em 20 de março de 2016]. Disponível em: http://seriesestatisticas.ibge.gov.br/ series.aspx? no $=4 \& \mathrm{op}=2 \& \mathrm{vcodigo}=\mathrm{MS} 11 \& \mathrm{t}=\mathrm{obitos}-$ causas-externas-suicidios-taxa-mortalidade. 
10. Power DV, Thompson L, Futterman A, GallagherThompsom D. Depression in Later Life: epidemiology, assessment, impact and treatment. In: Gotlib IH, Hammen CL, editors. Handbook of Depression. New York: Guilford Press; 2002. p. 560-80.

11. Organização Mundial de Saúde. Relatório sobre saúde no mundo 2001. Saúde mental: nova concepção, nova esperança. Escritório Central da Oficina PanAmericana de Saúde, Tradutor. Genebra: OMS; 2002.

12. Carvalho ILN. Uso de psicofármacos em adolescentes atendidos pelos centros de atenção psicossocial infanto-juvenil de Fortaleza-CE [Dissertação]. Fortaleza: Universidade de Fortaleza; 2012.

13. Cavalcante FG, Minayo MCS, Mangas RMN. Diferentes faces da depressão no suicídio em idoso. Ciênc Saúde Coletiva. 2013;18(10):2985-94.

14. Silva JC, Herzog LM. Psicofármacos e psicoterapia com idosos. Psicol Soc. 2015;27(2):438-48.

15. Betz ME, Arias AS, Segal DL, Miller I, Camargo Jr CA, Bourdreaux ED. Screening for suicidal thoughts and behaviors in older adults in the emergency department. J Am Geriatric Soc. 2016;64(10):72-7.

16. Organização Mundial de Saúde. Mental health suicide preventtion. Genebra: WHO; 2007.

17. Almeida OP, McCaul K, Hankey GJ, Yeap BB, Golledge J, Flicker L. Suicide in older men: the health in men cohort study. Prev Med. 2016;20(93):33-8.

18. George B, Kumar PNS. Risk factors for suicide in elderly in comparison to younger age groups. Indian J Psychiatry. 2015;57(3):249-54.

19. Cavalcante FG, Minayo MCS. Autópsias psicológicas e psicossociais em idoso que morreram por suicídio no Brasil. Ciênc Saúde Coletiva. 2012;17(8):1943-54.

20. Centro de Assistência Toxicológica, Figueiredo SMFB, Veras MSB, Gonçalves MEP, Amaral DA, Fonseca Neto MDF, Verde JSL, et al. Intoxicações Agudas. Guia prático para atendimento. Fortaleza; 2011. No Prelo.

21. Santos AS, Legay LF, Lovisi GM. Substâncias tóxicas e tentativas e suicídios: considerações sobre acesso e medidas restritivas. Cad Saúde Coletiva. 2013;21(1):53-61.
22. Secoli SV. Polifarmácia: interações e reações adversas no uso de medicamentos por idosos. Rev Bras Enferm. 2010;63(1):136-40.

23. Martins GA, Acurcio FA, Franceschini SCC, Priore SE, Ribeiro AQ. Uso de medicamentos potencialmente inadequados entre idosos do município de Viçosa, Minas Gerais, Brasil: um inquérito de base populacional. Cad Saúde Pública. 2015;31(11):2401-12.

24. Abi-Ackel, MM. Prevalência e fatores associados ao uso de psicofármacos entre idosos residentes na comunidade na Região Metropolitana de Belo Horizonte [Dissertação]. Belo Horizonte: Fundação Oswaldo Cruz, Centro de Pesquisas René Rachou; 2015.

25. Vukcevi NP, Ercegovic GV, Djordjevic S, Stosic JJ. Benzodiazepine poisoning in elderly. Vojnosanit Pregl. 2016;73(3):234-8.

26. Birman J. Mal-estar na atualidade: a psicanálise e as novas formas de subjetivação. Rio de Janeiro: Civilização Brasileira; 2011.

27. Oyama H, Fujita M, Goto M, Shibuya H, Sakashita T. Outcomes of community-based screening for depression and suicide prevention among Japanese elders. Gerontologist. 2006;46(6):821-6.

28. Oude Voshaar RC, Van der Veen DC, Hunt I, Kapur N. Suicide in late-life depression with and without comorbid anxiety disorders. Int J Geriatr Psychiatry. 2016;31(2):146-52.

29. Sadock B, Sadock VA, Sussman N. Manual de farmacologia psiquiátrica de Kaplan \& Sadock. $6^{a}$ ed. Porto Alegre: Artmed; 2015.

30. Oh DJ, Park JY, Oh M, Kim K, Hong J, Kim T, et al. Suicidality-based prediction of suicide attempts in a community-dwelling elderly population: Results from the Osan Mental Health Survey. J Affect Disord. 2015;15(184):286-92.

31. Chachamovich E, Stefanello S, Botega N, Turecki G. Quais os recentes achados sobre a associação entre depressão e suicídio? Rev Bras Psiquiatr. 2009;31(1):18-25.

32. Gutierrez DMD, Sousa ABL, Grubits S. Vivências subjetivas com idosos com ideação e tentativa suicida. Ciênc Saúde Coletiva. 2015;20(6):1731-40. 